\title{
https://doi.org/10.46813/2021-134-157 \\ ESTIMATION OF THE ROLE OF RADIATION IN THE PLASMA OF ELECTRIC ARC DISCHARGE BETWEEN CU-C COMPOSITES
}

\author{
A. Veklich, S. Fesenko, A. Murmantsev, V. Boretskij \\ Taras Shevchenko National University of Kyiv, Kyiv, Ukraine \\ E-mail: murmantsev.aleksandr@gmail.com
}

\begin{abstract}
This work is devoted to investigation of the radiation in the plasma of electric arc discharge between $\mathrm{Cu}-\mathrm{C}$ composite electrodes and estimation of its contribution during the determination of electron density from the energy balance equation (Elenbaas-Heller). The contribution of radiation energy in heat transfer is estimated as well. The calculation is carried out based on the preliminary experimentally obtained radial distribution of plasma temperature. For the correct solution of the energy balance equation, a Gaussian approximation of the plasma temperature profile is used. Estimation of the total current was used as a criterion for the need to take into account the radiation in the diagnostics of electric arc plasma.
\end{abstract}

PACS: 52.70.-m

\section{INTRODUCTION}

The development of sliding contacts for energy transfer to a moving consumer is an important area of power industry and electrical engineering [1]. Copper and its alloys, in particular with aluminium, low-carbon or graphitized steel, powder materials based on iron, carbon and metal-carbon etc., are often used as materials of sliding contacts. Moreover, there is still no single solution to the problem of choosing the optimal composition of contacts.

First of all, it is necessary that the material used for these elements provides reliable current collection, does not undergo intense wear, be affordable and inexpensive.

It is difficult to meet such requirements due to the fact that the material of current-collecting elements must have a number of incompatible properties, namely: good mechanical and antifriction properties, low resistivity and transient electrical resistance, high resistance to electrical erosion. In addition, it is necessary that the material of the current collector element guarantees reliable operation of the high-current sliding contact in difficult climatic conditions: with significant fluctuations in temperature, humidity and contact failure [2]. Under such extreme operating conditions, there is significant electrical erosion of the contact pair, due to the high temperature and the occurrence of breaking electric arcs.

Most often, sliding contacts are based on graphite, which has excellent lubricating properties, high heat resistance and low cost. The only disadvantage of graphite is its relatively high electrical resistance, which can be reduced with copper-graphite composites.

The above-mentioned electric discharge between sliding contacts leads to their intensive wear, so it is important to study such electrical erosion processes, which were partially performed by the authors of [3 - 5], who studied the effect of DC and AC arc discharge on the electrode surface. Unfortunately, in these investigations the spatial resolution was not provided. Moreover, there are no works that would be devoted to estimating the effect of radiation during the diagnostics of such type of plasma.
Thus, the main aim of this work is to estimate the role of the radiation in the plasma of electric arc discharge between composite $\mathrm{Cu}-\mathrm{C}$ electrodes, as well as to provide the diagnostic of such plasma with spatial resolution.

\section{ELENBAAS-HELLER EQUATION}

In the case of axial symmetry of the arc discharge, the energy balance equation (Elenbaas-Heller) is convenient to write in a cylindrical coordinate system [6]:

$$
\sigma(r) E^{2}=-\frac{1}{r}\left[\frac{d}{d r}\left(r \lambda(r) \frac{d T(r)}{d r}\right)\right]+\rho(r),
$$

where $\sigma(r), \lambda(r), T(r), \rho(r)$ are the radial distributions of electrical conductivity, thermal conductivity, temperature and density of radiation energy, respectively. $E$ is electric field strength of the positive column (directed along the $\mathrm{Z}$ axis of the cylindrical coordinate system). It should be noted, that equation (1) does not take into account the convective cooling of the arc discharge, the contribution of which can be significant.

It can be seen from equation (1) that at the introduced power into the discharge, the consideration of radiation will affect the corresponding distributions of the transport coefficients, namely: electrical and thermal conductivity. At the known temperature and the value of the electric field strength (which are preliminary experimentally determined), the behaviour of these coefficients can be analysed. As follows from [7], the thermal conductivity of plasma weakly depends on admixtures of electrode origin and insignificantly differs from the thermal conductivity of pure air. However, it was found [7] that the electrical conductivity of plasma increases significantly with the addition of copper, which is explained by its relatively low ionization potential. Therefore, the thermal conductivity of pure air was used in the calculation of the plasma electrical conductivity by equation (1) in this work.

Plasma temperature was experimentally determined by Boltzmann plots technique. The temperature profile obtained in such manner is not a smooth function. This is primarily a consequence of the application of the Abel integral transform, which is performed by the Bockasten method at 10 points [8]. This circumstance is critical for equation (1), because it assumes finding the 
first and second derivatives of the temperature distribution. Therefore, in this work, the temperature distribution was always approximated by a smooth function before substitution into equation (1). As can be seen from Fig. 1 gives a good result approximation of the Gaussian function with parameter $w$ of the form:

$$
T(r)=T_{0}+\left(T_{\max }-T_{0}\right) e^{-\frac{r^{2}}{w^{2}}} .
$$

The obvious advantage of the approximation of the form (2) is the yield to ambient temperature $T_{0}$ at significant distances $r$ from the discharge and zero value of the first derivative on the discharge axis, where $T_{r=0}=T_{\max }$.

The plasma temperature between $\mathrm{Cu}-\mathrm{C}$ electrodes, determined by Boltzmann plots technique, and its approximation by the Gaussian function of the form (2) are shown in Fig. 1.

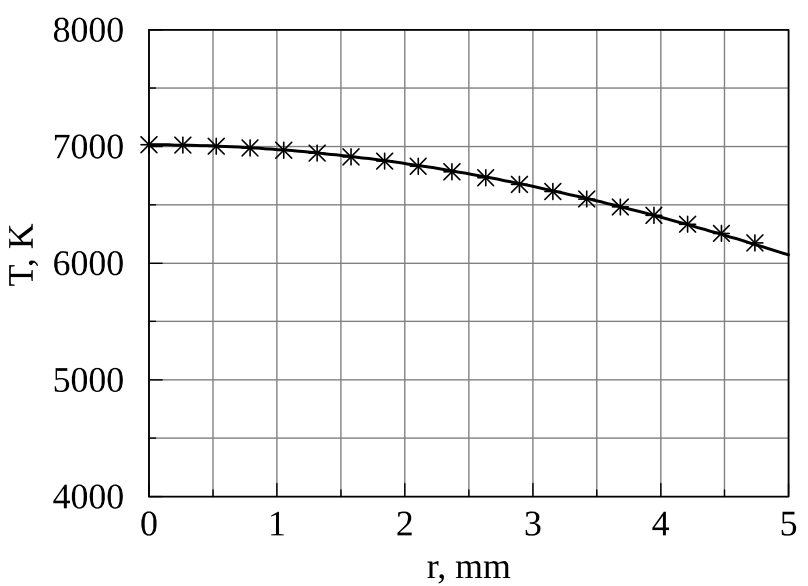

Fig. 1. Plasma temperature distribution of electric arc discharge at a current of $30 \mathrm{~A}$ between composite $\mathrm{Cu}-\mathrm{C}$ electrodes and its approximation by the Gaussian function

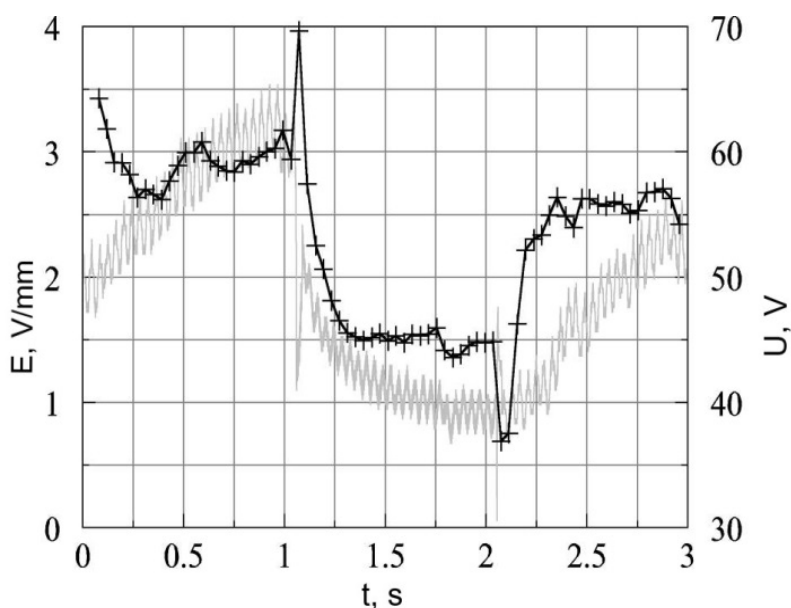

Fig. 2. Electric field strength of the positive column

(black curve) and the oscillogram of arc voltage (grey curve) of plasma of discharge at current of $30 \mathrm{~A}$ between composite $\mathrm{Cu}$-C electrodes in the air

The temporal evolution of the electric field strength of the positive column [9] and the voltage drop of arc discharge at current of $30 \mathrm{~A}$ are shown in Fig. 2. One can see, the electric field strength of arc discharge between composite $\mathrm{Cu}-\mathrm{C}$ electrodes is $1.5 \mathrm{~V} / \mathrm{mm}$.

\section{METHOD OF RADIATION POWER ESTIMATION}

At the first stage, determination of the electron density from the electrical conductivity of the plasma is considered. The distribution of electrical conductivity can be expressed from equation (1) in the form:

$$
\sigma(r)=-\frac{1}{r E^{2}}\left[\frac{d}{d r}\left(r \lambda(r) \frac{d T(r)}{d r}\right)\right]+\frac{\rho(r)}{E^{2}} .
$$

On the other hand, the electrical conductivity of plasma can be written as:

$$
\sigma(r)=e N_{e}(r) \mu_{e}(r) \text {. }
$$

After some transformations described in [10], equations (3) and (4) can be expressed as follows:

$N_{e}(r)=\frac{m_{e} \sigma(r)}{e^{2}} \sum_{p} N_{p} \int_{0}^{\infty} \sqrt{\frac{2 E_{e l}}{m_{e}}} Q_{e-p}\left(E_{e l}\right) f\left(E_{e l}\right)$,

where $N_{p}$ is the concentration of particles of grade "p", $Q_{e-p}$ is a cross section of electron scattering on particles of a grade "p", $f\left(E_{e l}\right)$ is a Maxwell energy distribution function of electrons.

Within the frameof this work, the scattering of electrons by neutral plasma particles $\mathrm{N}_{2}, \mathrm{~N}, \mathrm{O}_{2}, \mathrm{O}, \mathrm{NO}$ is taken into account.

The radiation power density $\rho(r)$ of the arc discharge can be estimated indirectly at the obtained plasma temperature distribution $T(r)$. Assuming that all atomic and molecular levels in plasma are populated according to the Boltzmann law, the power density of particles (atoms, molecules, ions and molecular ions) of a corresponding grade "A" can be obtained by summing the intensity of all spectral lines, spectroscopic constants of which are described in the literature [11 - 15]:

$$
\rho_{A}(r)=\frac{h N_{A}}{Z_{A}} \sum_{k} A_{k i} g_{k} v_{k i} e^{-\frac{E_{k}}{k_{B} T(r)}},
$$

where $\rho_{A}(r)$ is the radiation power density of particles of grade "A", $h$ is the Planck constant, $N_{A}$ is the concentration of particles of grade " $\mathrm{A}$ ", $A_{k i}$ is the Einstein coefficient of spontaneous radiation, $g_{k}$ is the statistical weight of the level from which the radiation transition occurs, $v_{k i}$ is a photon frequency, $E_{k}$ is the energy of the upper level from which the transition takes place, $k_{B}$ is the Boltzmann constant, $Z_{A}$ is the partition function of the particle of grade " $\mathrm{A}$ ". The concentration of particles of grade " $\mathrm{A}$ " is the only unknown parameter in equation (6). The qualitative content of plasma is known in advance, and the quantitative can be calculated by the method described in previous work [17], based on the temperature and electron density distributions.

Therefore, at the initial stage the electrical conductivity (1) and electron density (5) are obtained without taking into account the plasma radiation. The obtained value of the electron density is used to calculate the plasma equilibrium composition [17] in the next step. Having the obtained concentration distributions of all plasma components, its radiation can be calculated from equation (6). At the next stage, the obtained radiation distribution is substituted into equation (1) and the electrical conductivity of the plasma is calculated taking into account the radiation. The resulting corrected elec- 
trical conductivity is used to determine the actual electron density from equation (5).

\section{RESULTS AND DISCUSSIONS}

The radial distribution of plasma conductivity without taking into account radiation was calculated (Fig. 3, n-curve), based on the temperature distribution (see Fig. 1) and the value of the electric field strength from equation (3). The distribution of plasma current density without taking into account radiation is shown in Fig. 4 (a-curve).

The total current is calculated according to the expression:

$$
I=2 \pi E \int_{0}^{R_{\max }} r \sigma(r) d r .
$$

The calculated to a radius of $R_{\max }=4.7 \mathrm{~mm}$ the total current is $19 \mathrm{~A}$, although the actual discharge current is $30 \mathrm{~A}$.

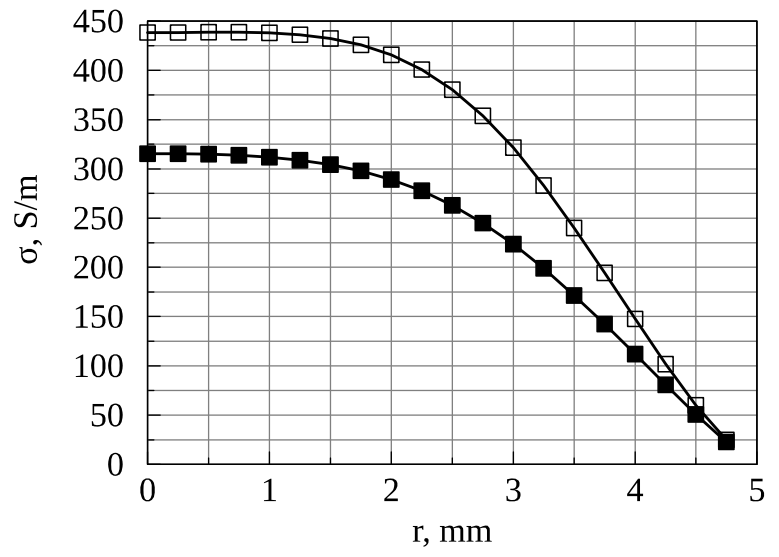

Fig. 3. The radial distribution of the electrical conductivity of electric arc plasma at a current of $30 \mathrm{~A}$ between composite $\mathrm{Cu}$-C electrodes, calculated without ( $\mathbf{(})$

and with (口) taking into account the radiation

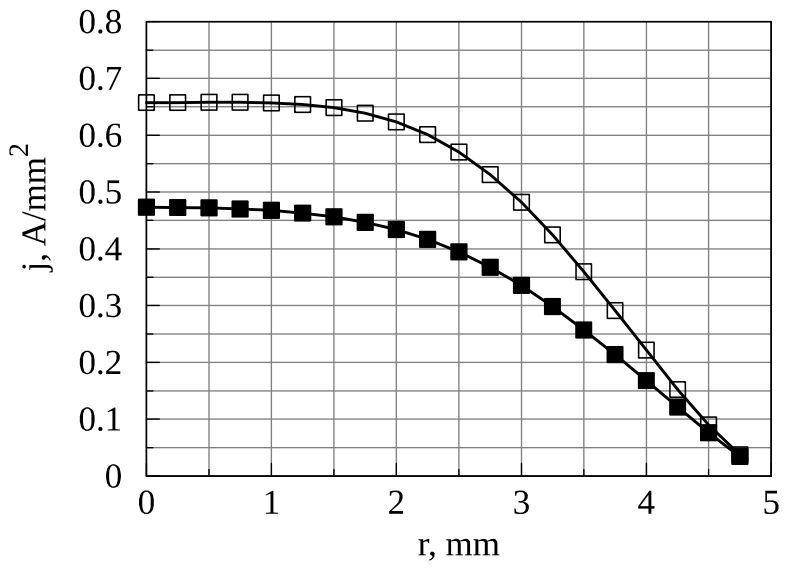

Fig. 4. Radial distribution of plasma current density of electric arc discharge at arc current of $30 \mathrm{~A}$ between

composite $\mathrm{Cu}$-C electrodes, calculated without (ロ)

and with (口) taking into account the radiation

The electron density, calculated from the distribution of the electrical conductivity of plasma (without taking into account the radiation) by equation (5), is shown in Fig. 5 (घ-curve). Based on the temperature and electron density distributions (obtained without taking into account the radiation), the component composition of the plasma was calculated and shown in Fig. 6. It was used to obtain the plasma radiation power density by equation (6). Its radial distribution is shown in Fig. 7. In the next step, the electrical conductivity of the plasma is calculated by equation (3) taking into account the contribution of radiation, shown in Fig. 7. The electrical conductivity distribution of arc discharge plasma at a current of $30 \mathrm{~A}$ between composite $\mathrm{Cu}-\mathrm{C}$ electrodes is shown in Fig. 3 ( $\square$-curve). The corresponding current density distribution is shown in Fig. 4 ( $\square$-curve).

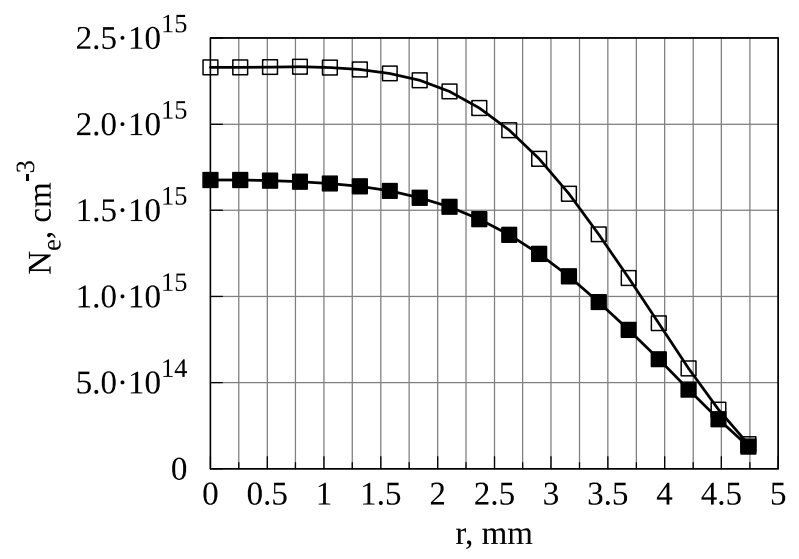

Fig. 5. Radial distribution of electron density of electric arc discharge plasma at current of 30 A between composite $\mathrm{Cu}$-C electrodes, calculated without ( $\mathbf{(})$ and with (口) taking into account the radiation

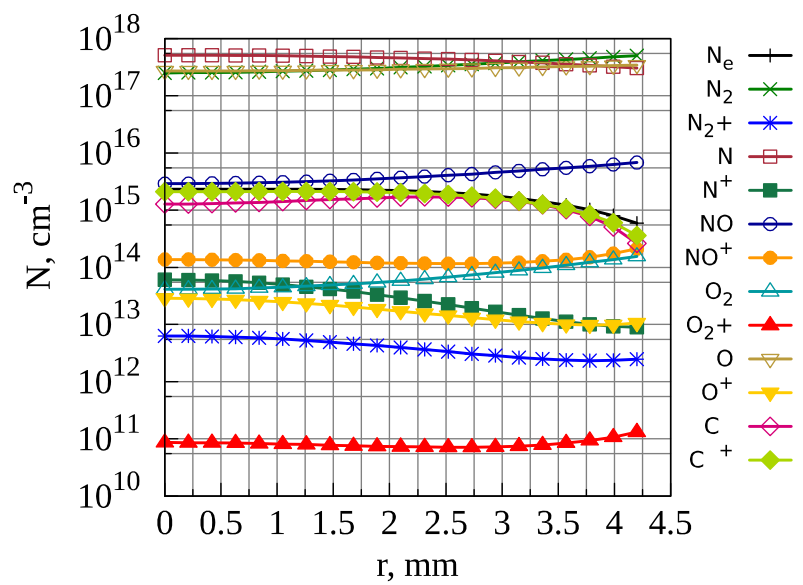

Fig. 6. Radial distribution of equilibrium plasma composition of electric arc discharge at current of $30 \mathrm{~A}$ between the composite $\mathrm{Cu}$-C electrodes

The total current of the arc discharge, calculated by equation (7) to a radius of $4.7 \mathrm{~mm}$, is $27 \mathrm{~A}$, which is much closer to the real $(30 \mathrm{~A})$ compared to the case without taking into account the radiation (19 A). Using the distribution of the electrical conductivity of the plasma, taking into account the radiation, the equation (5) was used to calculate the distribution of the electron density of plasma taking into account the radiation (see Fig. 7, $\square$-curve). Additionally, Fig. 7 shows the distribution of heat transfer in the plasma calculated as $\sigma E^{2}$, where the electrical conductivity is used, taking into account the radiation. As one can see from Fig. 7, on the axis of the discharge the radiation energy is $27 \%$ of heat transfer and can no longer be neglected.

The arc discharge plasma between $\mathrm{Cu}-\mathrm{C}$ electrodes contains air derivatives, atoms and ions of elements of electrode origin and various possible compounds of these elements with air components. 


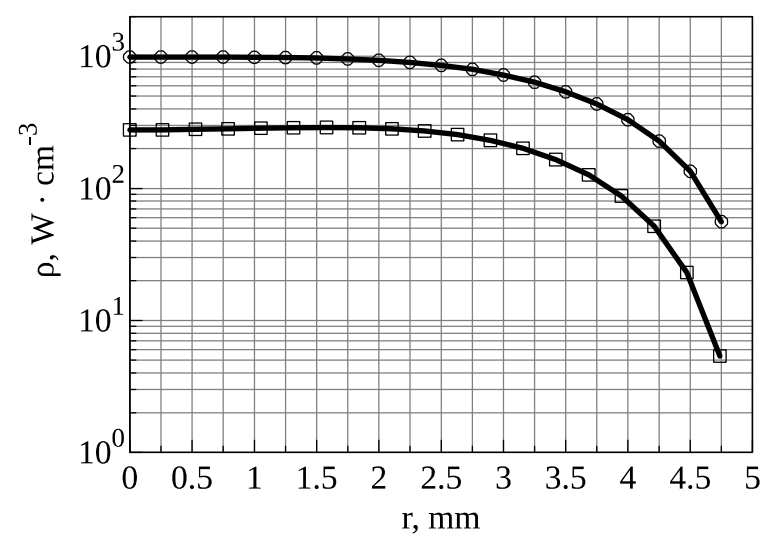

Fig. 7. Radial distribution of density of radiation power of electric arc discharge plasma at current of $30 \mathrm{~A}$ between composite $\mathrm{Cu}$-C electrodes ( $\square$ ) and density of heat transfero $E^{2}$ in plasma (O)

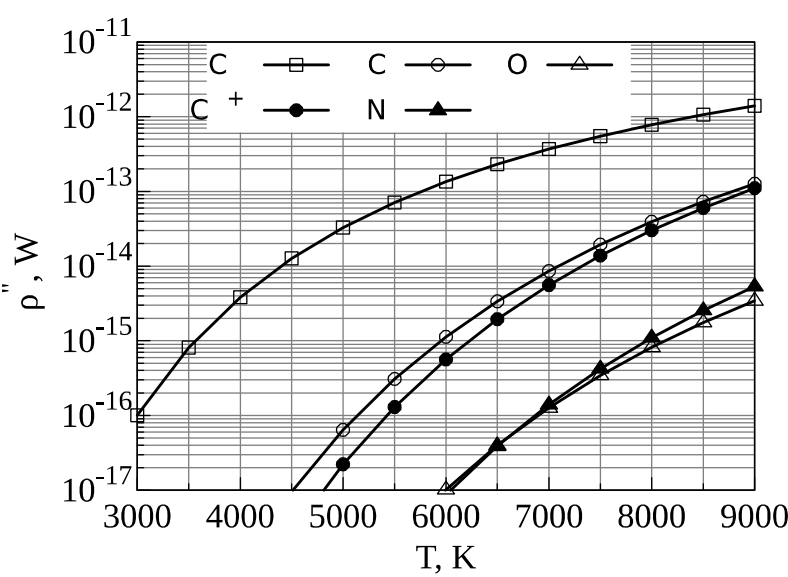

Fig. 8. Temperature dependence of radiation power per one atom/ion

However, only the following plasma components are taken into account in this work: $\mathrm{O}_{2}, \mathrm{O}, \mathrm{O}^{+}, \mathrm{N}_{2}, \mathrm{~N}, \mathrm{~N}^{+}$, $\mathrm{O}_{2}^{+}, \mathrm{N}_{2}^{+}, \mathrm{NO}, \mathrm{NO}^{+}, \mathrm{Cu}, \mathrm{Cu}^{+}, \mathrm{C}, \mathrm{C}^{+}$. Other components of plasma are considered insignificant due to their low concentration and high ionization potential. Although the plasma of the electric arc discharge between composite $\mathrm{Cu}-\mathrm{C}$ electrodes (similarly to the plasma between copper electrodes) contains a large number of different particles, the main contribution to the radiation is contributed by copper atoms. This is illustrated by the dependence of the radiation power per one atom/ion (Fig. 8) calculated by equation (6) for atoms of copper, carbon, nitrogen, oxygen and copper ion. This peculiarity is explained by the structure of atomic (ionic) levels. Therefore, to estimate the radiation in this case, only copper atoms can be considered. It should be noted, that the emission of molecular bands were not considered in this work. However, it can play significant role and should be under careful study in the future investigations.

\section{CONCLUSIONS}

The distributions of electrical conductivity and electron density were obtained by the estimation of the energy balance of the positive column of electric arc discharge between $\mathrm{Cu}-\mathrm{C}$ composite electrodes. The role of radiation energy losses was estimated and taken into account in the Elenbaas-Heller equation.
It was found that the total current of the arc discharge with taking into account radiation was as close as possible to the real one, compared to the case with excluding radiation.

Additionally, it was found that the radiation energy is $27 \%$ of heat transfer on the axis of the discharge at arc current of $30 \mathrm{~A}$, and it cannot be neglected.

\section{ACKNOWLEDGEMENTS}

This work has been carried out within the framework of the EURO fusion Consortium and has received funding from the Euratom research and training programme 2014-2018 and 2019-2020 under grant agreement No 633053. The views and opinions expressed herein do not necessarily reflect those of the European Commission.

In addition, authors are grateful to the partial support of these studies in the frame of project 19БФ052-02 of MES of Ukraine: "Investigation of properties of lowtemperature gas-discharge plasma for technological applications".

The authors also express their gratitude to Ministry of Education and Science of Ukraine for the support of project 21БП052-01 "Applications of electric discharge plasma with condensed dispersed phase".

\section{REFERENCES}

1. S. Fesenko, V. Boretskij, A. Veklich. Pulse power supply of electric arc discharges // Bulletin of Shevchenko National University of Kyiv. 2010, v. 14, p. 51-53.

2. V.Ya. Berent. Materials and properties of electrical contacts. M.: "Intekst", 2005, 408 p.

3. G. Wu, Y. Zhou, G. Gao, J. Wu, W. Wei. Arc Erosion Characteristics of $\mathrm{Cu}$-Impregnated Carbon Materials Used for Current Collection in High-Speed Railways // IEEE Transactions on Components, Packaging and Manufacturing Technology. 2018, v. 8(6), p. 1014-1023.

4. W. Wangang, W. Guangning, G. Guoqiang, B. Wang, Zh. Lijun, C. Yi, L. Donglai. Experimental Study of Electrical Characteristics on Pantograph Arcing // 1st International Conference on Electric Power Equipment - Switching Technology. Xi'an China. 2011, p. 602-607.

5. G. Guoqiang, H. Jing, W. Wenfu, H. Haixing, Zh. Guangya, W. Guangning. Dynamics of Pantograph - Catenary Arc During the Pantograph Lowering Process // IEEE Transactions on Plasma Science. 2016, v. 44(11), p. 2715-2723.

6. E.I. Asinovsky, A.V. Kirillin, V.L. Nizovsky. Stabilized electric arcs and their application in thermophysical experiment. M.: "Fizmatlit", 2008, 264 p.

7. V.F. Boretskij, Y. Cressault, Ph. Teulet, A.N. Veklich. Plasma of electric arc discharge in carbon dioxide with copper vapours // XVIX-th Symposium on Physics of Switching Arc. 2011, p. 5.

8. K. Bockasten. Transformation of Observed Radiances into Radial Distribution of the Emission of a Plasma // JOSA. 1961, v. 51(9), p. 943-947.

9. A.M. Veklich, S.O. Fesenko, L.O. Krychko, V.F. Boretskij, M.M. Kleshych, M.Ye. Holovkova. Peculiarities of electric arc discharge between com- 
posite $\mathrm{Cu}-\mathrm{C}$ electrodes // Proceedings of the Institute for Problems of Materials Science. I.N. Frantsevich National Academy of Sciences of Ukraine. Series "Composite, layered and gradient materials and coatings. Electrical contacts and electrodes." 2016, p. $36-60$.

10. A. Veklich, S. Fesenko, V. Boretskij, Y. Cressault, A. Gleizes, Ph. Teulet, Y. Bondarenko, L. Kryachko. Thermal plasma of electric arc discharge in air between composite $\mathrm{Cu}-\mathrm{C}$ electrodes // Problems of Atomic Science and Technology. 2014, № 6(90), p. 226-229.

11. A. Zaidel'. Tables of Spectral Lines. Springer US. 1970, 782 p.

12. Yu. Ralchenko. NIST Atomic Spectra Database (version 3.1.5) [Online] / Yu. Ralchenko, A.E. Kramida, J. Reader, et al. // Gaithersburg, MD: National Institute of Standards and Technology. accessed 17.12.2010. http://physics.nist.gov/asd3.
13. Ch. Corliss, U. Bozman. Transition Probabilities and Oscillator Strengths of 70 elements. Moscow, 1968, 562 p.

14. R.L. Kurucz. Atomic Line Data Kurucz CD-ROM № 23 / R.L. Kurucz and B. Bell - Cambridge, Mass.: Smithsonian Astrophysical Observatory, 1995.

15. C.H. Corliss. Spectral-Line Intensities and gf-Values in the First Spectrum of Copper // J. Research NBS (Phys. and Chem.). 1962, v. 66(6), p. 497-502.

16. R.L. Kurucz. Table of Semiempirical gf Values / R.L. Kurucz, E.A. Peytremann - <SAO Spec. Report No. $362(1975)>1975$ SAOSR.362.....K.

17. S.O. Fesenko, M.M. Kleshich, A.N. Veklich. Investigation of nonequilibrium in plasma of arc discharge between melting electrodes // Problems of Atomic Science and Technology. 2018, № 6(118), p. 274-277.

Article received 14.06.2021

\section{ОЦЕНКА РОЛИ ИЗЛУЧЕНИЯ В ПЛАЗМЕ ЭЛЕКТРОДУГОВОГО РАЗРЯДА МЕЖДУ КОМПОЗИТАМИ Си-С}

\section{А. Веклич, С. Фесенко, А. Мурманцев, В. Борецкий}

Работа посвящена исследованию излучения в плазме электродугового разряда между композитными СuС-электродами, а также оценке его вклада при определении электронной концентрации из уравнения энергетического баланса (Эленбааса-Геллера). Также оценивается вклад энергии излучения в процессы теплообмена. Расчет проводится на основе предварительно экспериментально полученного радиального распределения температуры плазмы. Для корректного решения уравнения баланса энергии используется аппроксимация профиля температуры плазмы функцией Гаусса. Оценка полного тока используется в качестве критерия необходимости учета излучения в диагностике плазмы электрической дуги.

\section{ОЦІНКА РОЛІ ВИПРОМІНЮВАННЯ В ПЛАЗМІ ЕЛЕКТРОДУГОВОГО РОЗРЯДУ МІЖ КОМПОЗИТАМИ Сu-C}

\section{А. Веклич, С. Фесенко, О. Мурманцев, В. Борецький}

Робота присвячена дослідженню випромінювання в плазмі дугового розряду між композитними $\mathrm{Cu}-\mathrm{C}$ електродами та оцінці його внеску при визначенні електронної концентрації з рівняння енергетичного балансу (Еленбааса-Геллера). Також оцінюється внесок енергії випромінювання в процеси теплообміну. Розрахунок проводиться на основі попередньо експериментально отриманого радіального розподілу температури плазми. Для коректного розв'язання рівняння енергетичного балансу використовується апроксимація профілю температури плазми функцією Гаусса. Оцінка загального струму використовується як критерій необхідності врахування випромінювання в діагностиці плазми електричної дуги. 